\title{
Fractional Generating Function from The Square Root of Two with A-B Goen Numbers
}

\author{
Stephanus Ivan Goenawan \\ Department of Industrial Engineering, \\ Atma Jaya Catholic University, \\ Jakarta, Indonesia 11480 \\ steph.goenawan@atmajaya.ac.id \\ *Correspondence: steph.goenawan@atmajaya.ac.id
}

\begin{abstract}
The square root of two is an irrational number that cannot be written as a fraction of the numerator and denominator. By using the generating function of $A-B$ Goen, from the resulting set of numbers, the sequence of $A-B$ Goen numbers can be obtained by selecting integer numbers. The A Goen numbers are generated from the generator function which have integer numbers, while the B Goen numbers are obtained from the sequence numbers. In this study, through the generating function of $A-B$ Goen, it can be proven that the division between the $A$ Goen number and the B Goen number in an infinite sequence will result the value of the square root of two.
\end{abstract}

Keywords: Numbers; Functions; Square Root of Two; Irrational Numbers.

Abstrak - Akar kuadrat dari dua adalah bilangan irasional yang tidak dapat dituliskan sebagai pecahan dari pembilang dan penyebutnya. Dengan menggunakan fungsi pembangkitan A-B Goen, dari himpunan bilangan yang dihasilkan, barisan bilangan A-B Goen dapat diperoleh dengan memilih bilangan bulat. Bilangan A Goen dihasilkan dari fungsi generator yang memiliki bilangan bulat, sedangkan bilangan B Goen diperoleh dari bilangan urut. Dalam penelitian ini, melalui fungsi pembangkitan A-B Goen dapat dibuktikan bahwa pembagian antara bilangan A Goen dan bilangan B Goen pada barisan tak hingga akan menghasilkan nilai akar kuadrat dari dua.

Kata kunci: Bilangan; Fungsi; Akar Kuadrat dari Dua; Bilangan irasional.

\section{PENDAHULUAN}

Definisi bilangan irasional adalah bilangan riil yang tidak dapat dibagi, artinya adalah hasil pembagiannya tidak pernah berhenti dan tidak pernah berulang (Lord 2008). Oleh karena itu, bilangan irasional tidak dapat dinyatakan sebagai $a / b$, dimana $a$ dan $b$ sebagai bilangan bulat dan nilai $b$ tidak sama dengan nol (Marshall 2012). Sehingga bilangan akar dari dua yang merupakan bilangan irasional juga tidak dapat ditulis dalam bentuk pecahan bilangan pembilang dan penyebut (Mitchell 2003). Dalam penelitian ini, dengan menggunakan fungsi pembangkit A-B Goen, dapat diperoleh urutan bilangan A Goen dan B Goen dari sekumpulan bilangan yang dihasilkan oleh fungsi pembangkit dengan cara menyeleksi bilangan yang integer. Bilangan A Goen dihasilkan dari fungsi pembangkit A-B Goen yang bernilai integer. Sedangkan bilangan B Goen diperoleh dari nilai urutan pada saat fungsi pembangkit A-B menghasilkan bilangan A Goen. Akhirnya, melalui fungsi pembangkit A-B Goen dapat dibuktikan bahwa pembagian antara bilangan A Goen sebagai pembilang dengan bilangan B Goen sebagai penyebut akan mendekati nilai akar dari dua, sedangkan secara teori bila menuju pada urutan tak hingga akan sama dengan nilai akar dari dua. Apakah hasil ini membuat kontradiksi dengan definisi bilangan irasional di atas? Tidak kontradiksi karena persyaratan urutan bilangan A Goen dan B Goen menuju tak hingga yang tidak mungkin terwujud.

Pada fungsi pembangkit A-B Goen yang mampu menghasilkan bilangan A Goen (AG) dan bilangan B Goen (BG) dengan cara menyeleksi secara komputasi bilangan yang dihasilkan fungsi pembangkit dengan syarat bilangan hanya bernilai integer. Selanjutnya akan didefinisikan suatu fungsi Integer (int) yang berfungsi untuk menyeleksi perhitungan akhir yang akan dihasilkan bilangan integer dan 
dikelompokkan ke dalam bilangan A Goen $\left(b_{A G}\right)$. Kemudian nilai urutannya akan menjadi bilangan B Goen $\left(b_{B G}\right)$.

Dalam penelitian ini akan dilakukan perhitungan secara komputasi sebanyak 33461 kali, kemudian dilakukan penyeleksian hasil melalui fungsi integer akan diperoleh hasil sebanyak 13 data bilangan AG dan bilangan BG. Perhitungan pembagian antara bilangan AG dengan bilangan $\mathrm{BG}$ dengan urutan bilangan makin besar, hasil perhitungannya akan mendekati nilai akar dari dua dan untuk pendekatan nilai akar dari dua yang benar hingga ketelitian 16 angka desimal adalah 1,414. 213.562.373.095. Selanjutnya juga akan dibuktikan bahwa pembagian antara bilangan A Goen sebagai pembilang dan bilangan B Goen sebagai penyebut pada nilai urutan bilangan B Goen menuju tak hingga akan menghasilkan nilai bilangan irasional akar dari dua.

\section{METODE PENELITIAN}

\subsection{Fungsi pembangkit A-B Goen}

Fungsi pembangkit A-B Goen adalah fungsi yang mampu menghasilkan bilangan A Goen (AG) dan bilangan B Goen (BG) dengan cara menyeleksi bilangan yang dihasilkan fungsi pembangkit dengan syarat bilangan hanya bernilai integer. Di bawah ini terdapat persamaan fungsi $y(t)$ sebagai pembangkit bilangan integer bilangan AG dan BG (Goenawan 2021):

$$
y(t)=\sqrt{(-1)^{t}+2 \cdot t^{2}}
$$

dimana $t$ adalah bilangan asli atau integer positif, $t=1,2,3, \ldots$

Selanjutnya juga perlu didefinisikan suatu fungsi Integer (int) yaitu fungsi yang mengambil atau menyeleksi bilangan apabila perhitungan hasil akhir menghasilkan bilangan integer (Gel'fand 1993). Sehingga hasil bilangan seleksi tersebut dapat dikelompokkan ke dalam bilangan A Goen $\left(b_{A G}\right)$. Bilangan AG dapat diperoleh apabila perhitungan fungsi $y(t)$ menghasilkan bilangan integer (Goenawan 2020), yang secara matematis dapat ditulis sebagai pers.(2)

$$
b_{A G}(t)=\operatorname{int}(y(t))
$$

dan nilai $t$ yang menghasilkan fungsi $y(t)$ bernilai bilangan integer adalah bilangan B Goen $\left(b_{B G}\right)$. Jadi $b_{B G}=\mathrm{t}$ dengan syarat $y(t)$ bernilai bilangan integer.

$$
b_{B G}(t)=t
$$

Di bawah ini terdapat contoh hasil sepuluh perhitungan fungsi $y(t)$ yang akan menghasilkan sebagian bilangan AG dan BG dengan cara menyeleksi hasil perhitungan yang berupa bilangan integer, terlihat pada tabel 1 di bawah ini:
Tabel 1. Hasil fungsi $y(t)$ pembangkit bilanganAG dan BG

\begin{tabular}{lr}
\hline$t$ & $y(t)$ \\
\hline 1 & 1 \\
\hline 2 & 3 \\
\hline 3 & 4,123106 \\
\hline 4 & 5,744563 \\
\hline 5 & \\
\hline 6 & 8,544004 \\
\hline 7 & 9,848858 \\
\hline 8 & 11,35782 \\
\hline 9 & 12,68858 \\
\hline 10 & 14,17745 \\
\hline
\end{tabular}

Sehingga berdasarkan tabel 1 di atas, hasil nilai bilangan keluaran fungsi $\operatorname{int}(y(t))$ yang termasuk bilangan AG adalah 1, 3 dan 7. Sedangkan yang termasuk kelompok bilangan BG adalah nilai $t$ yang menghasilkan bilangan $\mathrm{AG}$ yaitu angka 1, 2 dan 5.

Selanjutnya setelah dilakukan komputasi perhitungan mulai dari $t=1$ hingga $t=33461$ terhadap fungsi pembangkit A-B Goen dari pers.(1), kemudian dilakukan penyaringan menggunakan fungsi integer akan diperoleh hasil berupa 13 data bilangan AG dan bilangan BG yang terdapat pada tabel 2 di bawah ini:

Tabel 2. Urutan Bilangan AG dan BG

\begin{tabular}{lr}
\hline$t=b_{B G}(t)$ & $b_{A G}(t)$ \\
\hline 1 & 1 \\
\hline 2 & 3 \\
\hline 5 & 7 \\
\hline 12 & 17 \\
\hline 29 & 41 \\
\hline 70 & 99 \\
\hline 169 & 239 \\
\hline 408 & 577 \\
\hline 985 & 1393 \\
\hline 2378 & 3363 \\
\hline 5741 & 8119 \\
\hline 13860 & 19601 \\
\hline 33461 & 47321 \\
\hline
\end{tabular}




\section{HASIL DAN DISKUSI}

\subsection{Pembuktian Fungsi Pembangkit A-B Goen}

Pembuktian persamaan pecahan bilangan irasional akar dua berupa nilai perbandingan antara bilangan A Goen dengan bilangan B-Goen akan menggunakan gabungan fungsi integer dan fungsi pembangkit bilangan A-B Goen yaitu dari pers.(1) dan pers.(2) di atas:

$$
\operatorname{int}(y(t))=\operatorname{int}\left(\sqrt{(-1)^{t}+2 \cdot t^{2}}\right)
$$
diperoleh:

dari pers.(2) bila disubstitusikan ke pers.(3)

$$
b_{A G}(t)=\sqrt{(-1)^{t}+2 \cdot t^{2}}
$$

dengan syarat pada ruas kanan harus menghasilkan bilangan yang integer, selanjutnya bila kedua ruas persamaan di atas saling dikuadratkan menjadi:

$$
b_{A G}(t)^{2}=(-1)^{t}+2 \cdot t^{2}
$$

bila pada pers.(5) dibagi dengan, kemudian didekati dengan limit nilai $t$ menuju tak hingga

$$
\lim _{t \rightarrow \infty}\left(\frac{b_{A G}(t)}{t}\right)^{2}=\lim _{t \rightarrow \infty}\left(\frac{(-1)^{t}}{t^{2}}+2\right)
$$

karena nilai limit

$$
\lim _{t \rightarrow \infty} \frac{(-1)^{n}}{t^{2}}=0
$$

maka pers.(6) dapat ditulis kembali menjadi

$$
\lim _{t \rightarrow \infty}\left(\frac{b_{A G}(t)}{t}\right)^{2}=2
$$

sehingga dengan melakukan operasi akar dikedua sisi pers.(8) dan mengganti penulisan notasi $t$ dengan akan diperoleh hubungan pers.(9) yang merupakan persamaan pecahan pada bilangan irasional akar dari dua yang dibangun dari pembagian antara bilangan A Goen sebagai pembilang dan bilangan B Goen sebagai penyebut dengan nilai $t$ atau urutan bilangannya menuju tak hingga.

$$
\lim _{t \rightarrow \infty} \frac{b_{A G}(t)}{b_{B G}(t)}=\sqrt{2}
$$

Dari urutan bilangan AG dan BG yang terdapat pada tabel 2 diatas maka bisa diperoleh hasil pembagian antara bilangan AG sebagai pembilang dengan bilangan BG sebagai penyebut pada tabel 3 sesuai pers.(9).
Tabel 3. Perbandingan Bilangan AG dan BG

\begin{tabular}{llr}
\hline$t=b_{B G}(t)$ & $b_{A G}(t)$ & $b_{A G}(t) / b_{B G}(t)$ \\
\hline 1 & 1 & $1,000.000 .000 .000 .00$ \\
\hline 2 & 3 & $1,500.000 .000 .000 .00$ \\
\hline 5 & 7 & $1,400.000 .000 .000 .00$ \\
\hline 12 & 17 & $1,416.666 .666 .666 .67$ \\
\hline 29 & 41 & $1,413.793 .103 .448 .28$ \\
\hline 70 & 99 & $1,414.285 .714 .285 .71$ \\
\hline 169 & 239 & $1,414.201 .183 .431 .95$ \\
\hline 408 & 577 & $1,414.215 .686 .274 .51$ \\
\hline 985 & 1393 & $1,414.213 .197 .969 .54$ \\
\hline 2378 & 3363 & $1,414.213 .624 .894 .87$ \\
\hline 5741 & 8119 & $1,414.213 .551 .646 .05$ \\
\hline 13860 & 19601 & $1,414.213 .564 .213 .56$ \\
\hline 33461 & 47321 & $1,414.213 .562 .057 .32$ \\
\hline
\end{tabular}

Bilangan yang terdapat pada Tabel 3, kolom 3 adalah pembagian antara bilangan AG dengan bilangan BG yang merupakan bentuk pecahan akar dari dua dan apabila urutan bilangan makin besar maka hasilnya akan makin mendekati nilai akar dari dua. Sebagai pembanding terdapat nilai pendekatan akar dari dua yang benar hingga 16 angka desimal yaitu: 1,414. 213.562.373.095.

\section{KESIMPULAN}

Fungsi pembangkit $y(t)$ pada pers.(1) yang merupakan fungsi pembangkit bilangan integer A Goen dan bilangan integer B Goen. Bilangan A Goen dapat diperoleh bila fungsi pembangkit A-B Goen menghasilkan bilangan integer pada urutan perhitungan $t$ tertentu. Sedangkan bilangan B Goen adalah bilangan integer $t$ yang menghasilkan bilangan A Goen. Pembagian antara bilangan A Goen sebagai pembilang dengan bilangan B Goen sebagai penyebut pada urutan bilangan tak terhingga akan menghasilkan nilai akar dari dua yang telah dibuktikan pada pers.(9). 


\section{DAFTAR PUSTAKA}

Goenawan, Stephanus Ivan. (2020). Comparison Simulation Analysis Of The Gradual Summation Of A Function With Recognition Of Direct Extrapolation Via IN Series. IJASST Univ. Sanata Dharma, Yogyakarta.

Goenawan, Stephanus Ivan. (Januari 2020). Order Theory I And II As Foundations For Finding Relationship Between Formulas, Engineering, Mathematics, and Computer Science (EMACS) Journal, Vol. 2 No. 1. hal 1 - 4, p-ISSN 1410-2765.

Goenawan, Stephanus Ivan. (2021). Fungsi Pembangkit Bilangan A-B Goen, Berguna Secara Komputasi Untuk Mencari Pecahan Pembilang dan Penyebut Pada Bilangan Irasional Akar Dari Dua. HKI: EC00202135535, 27 Juli 2021., Link Channel AtmaJaya: https://youtu.be/D7ue-knyPBs

Gel'fand, Izrael M.; Shen, Alexander. (1993). Algebra (3rd ed.). Birkhäuser. p. 120. ISBN 0-8176-3677-3.

Lord, Nick. (November 2008). "Maths bite: irrational powers of irrational numbers can be rational", Mathematical Gazette 92. p. 534.

Marshall, Ash J., and Tan, Yiren. (March 2012). "A rational number of the form aa with a irrational", Mathematical Gazette 96. pp. 106-109.

Mitchell, Douglas W. (November 2003). "Using Pythagorean triples to generate square roots of I2", Mathematical Gazette 87. 499-500.

Katz, V.J. 1995. "Ideas of Calculus in Islam and India." Mathematics Magazine (Mathe-matical Association of America), 68(3):163-174.

Krantz, Steven George (2006). Calculus: Single Variable, Volume 1. Springer Science \& Business Media. p. 248. ISBN 978-1-931914-59-8.

McQuarrie, Donald A. (2003). Mathematical Methods for Scientists and Engineers, University Science Books. ISBN 978-1-891389-24-5

Salas, Saturnino L.; Hille, Einar; Etgen, Garret J. (2007). Calculus: One and Several Variables (10th ed.). Wiley. ISBN 978-0-471-69804-3.

Stewart, James (2012). Calculus: Early Transcendentals, 7 th ed., Brooks Cole Cengage Learning. ISBN 978-0-538-497 90-9

Thomas, George B., Maurice D. Weir, Joel Hass, Frank R. Giordano (2008), Calculus, 11th ed., AddisonWesley. ISBN 0-321-48987-X

Zill, Dennis G.; Wright, Scott; Wright, Warren S. (2009). Calculus: Early Transcenden-tals (3 ed.). Jones \& Bartlett Learning. p. xxvii. ISBN 978-0-763759957. 